\title{
Geological controls and tidal forcing of submarine groundwater discharge from a confined aquifer in a coastal sand dune system
}

\author{
D. Holliday, ${ }^{1}$ T. C. Stieglitz, ${ }^{1,2}$ P. V. Ridd, ${ }^{1}$ and W. W. $\operatorname{Read}^{1}$
}

Received 13 March 2006; revised 16 August 2006; accepted 22 August 2006; published 19 April 2007.

[1] Submarine groundwater discharge (SGD) into the ocean is increasingly recognized as an important component of land-ocean interaction. Numerous geological settings may be the source of terrestrially derived SGD, including spatially extensive sand dune systems, which are a common coastal setting in tropical, subtropical, and temperate regions throughout the world. Within the catchment of the Great Barrier Reef lagoon, numerous large-scale sand dune systems exist. Creeks and rivers draining these systems are largely absent; however, terrestrially derived groundwater discharges from discrete springs in the intertidal zone. The geological and hydrological controls of the discharge were investigated, using a combination of geological, geophysical, and hydrological methods. From sedimentary and geoelectric data it is inferred that a unit of sandy clay provides a confinement of the shallow aquifer system in the dune complex, with groundwater discharging where this layer is breached. Groundwater discharge flux was inversely correlated with tidal water level, but remained positive throughout the tidal cycle. A simple hydrological model indicates that the continuous discharge is the result of a change in hydraulic pressure of the confined aquifer in response to tidal forcing at the seaward limit of the aquitard, which is a previously undescribed effect of tidal modulation of SGD. The observed groundwater discharge is likely to have a significant effect on the biogeochemistry of the coastal environment, particularly in the absence of surface water drainage.

Citation: Holliday, D., T. C. Stieglitz, P. V. Ridd, and W. W. Read (2007), Geological controls and tidal forcing of submarine groundwater discharge from a confined aquifer in a coastal sand dune system, J. Geophys. Res., 112, C04015, doi:10.1029/2006JC003580.

\section{Introduction}

[2] The direct discharge of groundwater to the ocean, termed Submarine Groundwater Discharge (SGD) is increasingly being recognized as "an integral part of coastal hydrology" [Bokuniewicz, 1980]. Submarine sources of terrestrially derived, fresh groundwater contribute to coastal hydrological processes and biogeochemical budgets of the near-shore zone. Generally, SGD from continental aquifers occurs along any seaward sloping coastline with a hydraulic gradient [Johannes, 1980]. In principle, groundwater may enter the coastal zone as diffuse shoreline (beach face) seepage or as point-source discharge, commonly associated with unconfined or confined aquifers, respectively. In order to assess the relevance of SGD to ecological processes in a particular region, an understanding of the underlying geology and of the driving hydrological forces is required. Stieglitz [2005] provides an overview of hydrogeological processes observed in northeast Australia. Amongst the

\footnotetext{
${ }^{1}$ Marine Geophysical Laboratory, School of Mathematical and Physical Sciences, James Cook University, Townsville, Queensland, Australia.

${ }^{2}$ Also at Australian Institute of Marine Science, Townsville, Queensland, Australia.

Copyright 2007 by the American Geophysical Union. 0148-0227/07/2006JC003580\$09.00
}

identified discharges is "Buiur Bindi", meaning "freshwater in the ocean" in the language of local indigenous people, at Elim Beach, northeast Australia (Figure 1). Fresh groundwater discharges from discrete springs on the intertidal flat, which have been known to the local indigenous people for thousands of years. These springs number in excess of 300 and range from approximately $2 \mathrm{~cm}$ to $2 \mathrm{~m}$ in diameter. Whilst significant recharge of the groundwater reservoir occurs only during the austral summer from December to April (Australian Bureau of Meteorology, http://www.bom. gov.au/climate/averages/tables/cw_031016.shtml), local indigenous people rely on the water supply from these springs throughout the year. Investigations of the geological controls and oceanographic forcing of SGD at Elim Beach carried out in May 2004 are reported here.

\section{Study Site}

[3] The coastline between Cape Bedford and Cape Flattery is dominated by an extensive sand dune field covering an area greater than $600 \mathrm{~km}^{2}$ (Figure 1). Within topographic lows in the dune complex, standing water and vegetated freshwater swamps are abundant [Timms, 1986]. Dune development is believed to have been intermittent throughout the Pleistocene and Holocene with periods of major dune development coinciding with marine transgressive 

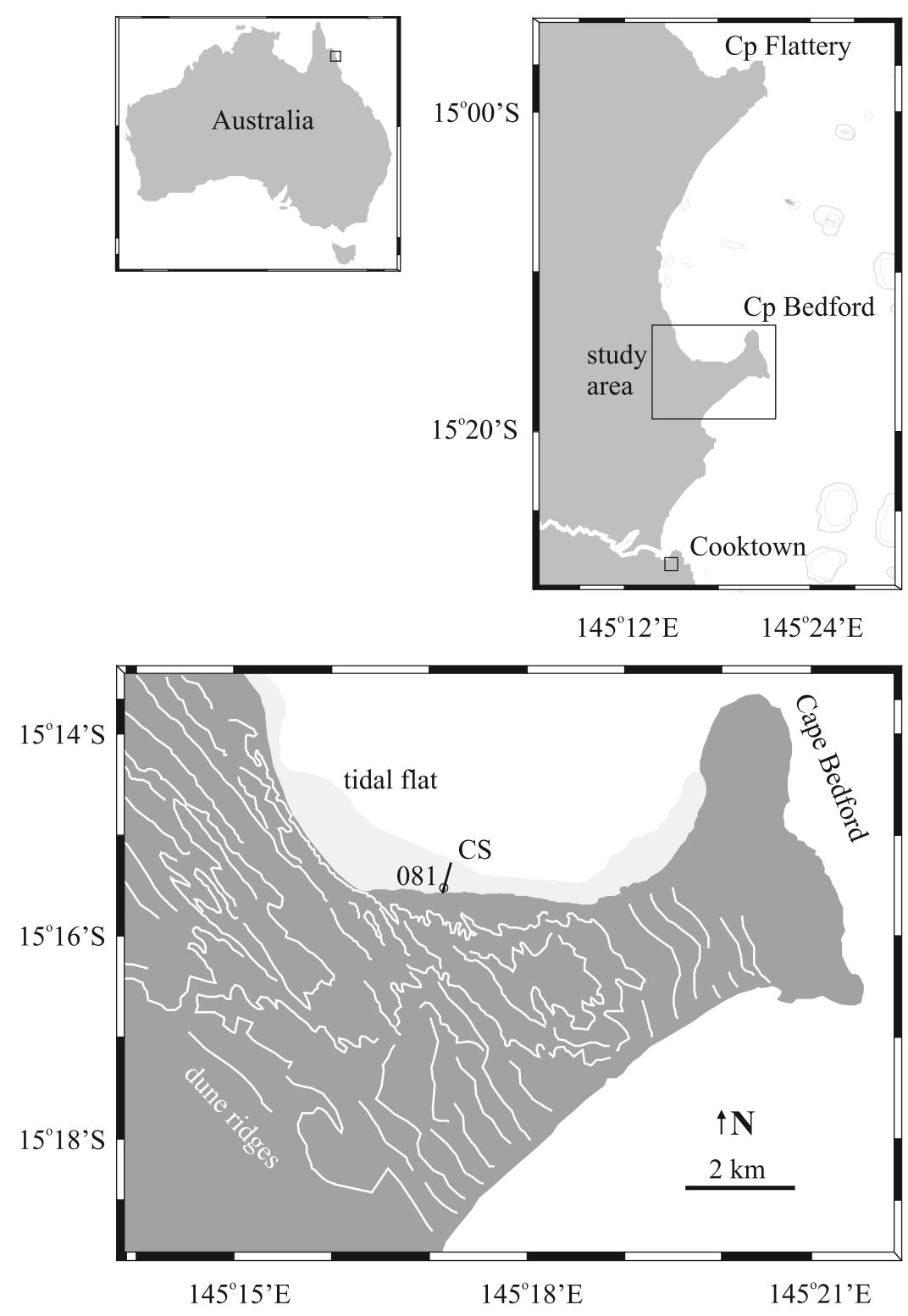

Figure 1. Location of the study site at Elim Beach, northeast Australia. The locations of the conductivity survey (CS) and of spring 081 are marked. Major dune ridges are marked, with heights ranging between 20 and $120 \mathrm{~m}$ above sea level.

events [Pye, 1982]. The climate in the region is seasonally humid tropical with approximately $75 \%$ of the average annual rainfall of $1750 \mathrm{~mm}$ precipitating between late December and late April (Australian Bureau of Meteorology, Cooktown Station). Stieglitz [2005] proposed a conceptual hydrological model for SGD, with the dune complex acting as a large "sponge", retaining groundwater beneath a shallow aquitard, with spring discharge occurring where the aquitard is breached.

[4] The study site is located at Elim Beach to the west of Cape Bedford (Figure 1). The beach is protected from dominant southeast trade winds by Cape Bedford, but lies exposed to north and northeast weather and the influence of occasional tropical cyclones. The region is mesotidal, experiencing semidiurnal tides with a diurnal asymmetry. The maximum spring tidal range is approximately $3 \mathrm{~m}$. A tidal flat extends approximately $550 \mathrm{~m}$ seaward of the high water mark at Elim Beach, and hosts numerous freshwater springs of variable sizes. At the shoreline, the beach vegetation is dominated by Melaleuca spp. A low erosional step marks the transition from beach face to beach ridge, and the beginning of an older vegetated dune complex. Directly behind the ridge, the gradient dips forming a freshwater wetland basin. Indigenous owners report that spring discharge in the intertidal zone is perennial, with only the driest years yielding a notable reduction of discharge. With the exception of the McIvor River approximately $15 \mathrm{~km}$ to the north of the study site, which predominantly drains low-lying areas landward of the dune complex, the absence of rivers and creeks from the bay results in limited surface water runoff.

\section{Methods}

[5] The geological and hydrological controls of the spring discharge at Elim Beach were investigated with a variety of 

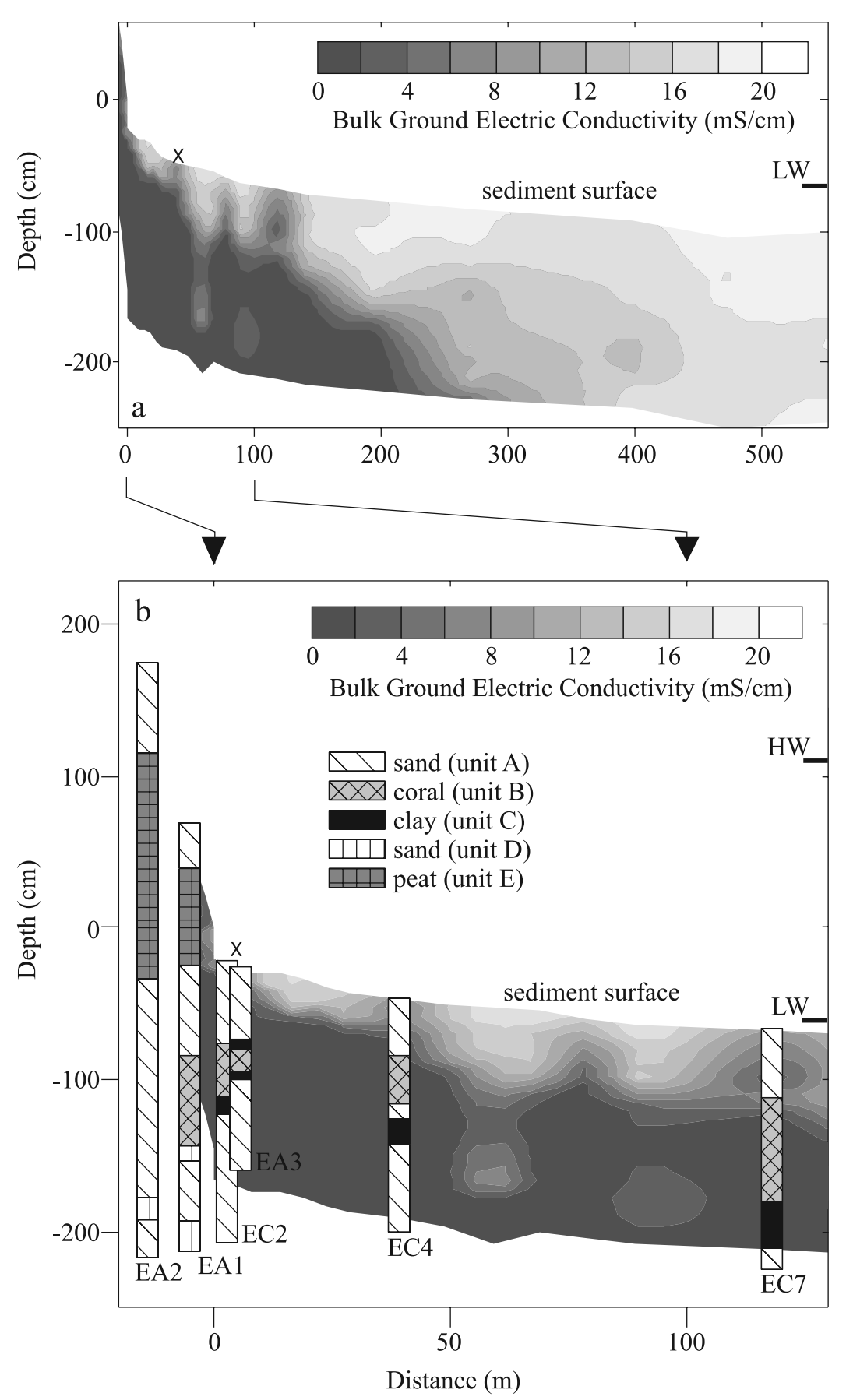

Figure 2. (a) Shore normal transect of bulk ground electric conductivity across the beach face and tidal flat and (b) inshore section of the transect together with core locations and stratigraphy. The location of spring 081 is marked with an $\mathrm{x}$, and the high-water (HW) and low-water (LW) marks during the experiments are indicated on the right-hand axis.

methods. In situ bulk ground electric conductivity was recorded along a shore normal transect CS across the tidal flat (Figures 1 and 2). The waterline at low tide marked the seaward extent of the transect. The local topography was surveyed with a theodolite; elevations and distances for all points are referenced to approximately Australian Height
Datum (AHD). Sediment cores were extracted at irregular intervals along the transect and inland thereof, using a hand auger and a vibrocorer. The extracted cores were logged, and bulk lithology $(>63 \mu \mathrm{m})$, grain size distribution and hydraulic conductivity were determined for all stratigraphic units. Hydraulic head and discharge rate were recorded from 
a representative spring (spring 081) located on the transect, approximately $20 \mathrm{~m}$ offshore from the high tide mark (Figure 1). Detailed descriptions of the methods are presented below.

\subsection{Bulk Ground Electrical Conductivity}

[6] In situ bulk ground electrical conductivity is a useful measure to qualitatively assess localized, small-scale variations in the spatial distribution of groundwater in marine sediments [Ridd and Sam, 1996; Stieglitz, 2005]. In coastal sediments, reduced bulk ground conductivity is often associated with fresh or brackish pore water [e.g., Stieglitz, 2005]. Electrical conductivity profiles were recorded along transect CS with a purpose-built conductivity probe, the design of which is described in detail by Stieglitz et al. [2000]. The probe consists of a steel rod with a Wenner array of electrodes at the bottom end. Bulk ground conductivity at different depths is measured by pushing the rod into the sediment. Data were recorded in $10 \mathrm{~cm}$ depth increments to a total depth of $140 \mathrm{~cm}$. The distance between profiles was between $2 \mathrm{~m}$ and $30 \mathrm{~m}$. From these profiles, a contoured transect of bulk ground conductivity was constructed by interpolation using the software package Surfer. The probe was calibrated by immersing it into seawater of known conductivity. Relative errors in conductivity are less than 5\% [Stieglitz et al., 2000].

[7] In addition, concurrent profiles of bulk ground conductivity and pore water salinity were recorded at selected sites, in order to establish the relationship between measured ground conductivity and pore water salinity. Pore water was sampled with minipiezometers consisting of $6 \mathrm{~mm}$ stainless steel pipe with four small holes at the tip. Maximum depth of penetration was $90 \mathrm{~cm}$. Pore water was extracted with a $60 \mathrm{ml}$ syringe connected to the open end of the piezometer with a clear plastic hose. The syringe was purged three times prior to measurement of pore water salinity with a Milwaukee MR100ATC handheld refractometer (accuracy of 1 practical salinity unit (psu)).

\subsection{Sediment Properties}

[8] In order to identify the sedimentary properties of the aquifer and confinement units, and to establish an estimate of the relative rate of water transport within each sedimentary unit, 6 cores were extracted along the conductivity transect (Figure 2b). The cores were logged visually (Figure 2b), and sediment grain size distributions were determined to establish a measure of relative sorting. A total of 38 samples (one sample of each unit from each core, Figure 2b) were wet-sieved at $1000 \mu \mathrm{m}$, and standard bulk grain size analyses were performed using a Mastersizer-X laser particle sizer (4-2000 $\mu \mathrm{m}$ grain size range).

[9] In addition, the hydraulic conductivity $\mathrm{K}$ of the stratigraphic units was determined on the basis of a standard measure of falling head [e.g., Marshall et al., 1996]. Each stratigraphic unit from vibrocore EC2 (representative for the sedimentary units occurring in all vibrocores) and a unit of peat found in auger cores EA1 and EA2 at the landward limit of the observation transect were assessed. Sediment samples of $3 \mathrm{~cm}$ thickness were cut from the cores at representative locations within each unit, using a syringe barrel ( $3 \mathrm{~cm}$ diameter) in a fashion similar to a cookie cutter. This way, alterations of the original sediment structure were minimized (note, however, that some alteration of the sediment structure may have occurred during coring and cutting the core). Each sample was retained in the openended $60 \mathrm{ml}$ syringe barrel of $3 \mathrm{~cm}$ diameter, and sieve mesh $(63 \mu \mathrm{m})$ was attached to the base. Sieve mesh of $63 \mu \mathrm{m}$ mesh size was chosen in order to minimize the loss of the fine grain fraction. The syringe was suspended so that the sieve mesh was at the base. Thirty $\mathrm{ml}$ of freshwater were added, equivalent to a hydraulic head of $4.5 \mathrm{~cm}$. The hydraulic conductivity $\mathrm{K}$ was calculated from the change in head in the syringe with time, applying standard calculations [e.g., Marshall et al., 1996].

\subsection{Hydraulic Head and Discharge Rate}

[10] A seepage meter consisting of an upside down plastic drum with a depth of $70 \mathrm{~cm}$ and a diameter of $42 \mathrm{~cm}$ was deployed in spring 081 [cf. Lee, 1977]. The base of the seepage meter was deployed directly on the hard, confining unit. No leakage on the outside of the seepage meter was observed for the duration of the experiments, indicating that the seepage meter contained the spring (i.e., the breach in the confining layer) adequately. A minor reduction in spring flow rate due to installation of the seepage meter may have occurred, and therefore measured flow rate and hydraulic head may slightly underestimate the unrestricted flow rate/ hydraulic head.

[11] At the sediment surface, a garden hose was connected to a hose fitting in the top of the seepage meter. A standpipe was connected to the seepage meter via the garden hose, and hydraulic head in the pipe measured. The measured head represents the hydraulic head in the confined aquifer. Hydraulic head difference was calculated by subtracting the tidal water level overlying the sediment surface from the hydraulic head in the standpipe (with respect to the sediment surface), whereby the density difference between freshwater in the standpipe and overlying seawater was corrected for. Absolute error for measurements of hydraulic head is estimated at $\pm 1 \mathrm{~cm}$. Subsequently, the standpipe was disconnected, and the discharge rate was determined by connecting a deflated 4-L plastic bladder to the seepage meter, and measuring discharge into the bladder per time. The relative error in discharge rate is estimated at $<5 \%$. Hydraulic head and discharge rate measurements were recorded at hourly intervals during the daytime. Measurements during the night were recorded as often as safety considerations permitted. A saltwater crocodile was sighted during data collection at night on 11 May. Therefore further data collection during that night was abandoned, and reassumed at first light. In the following night, a $20 \mathrm{~m}$ long hose was connected to the seepage meter in order to move the data collection point to the water's edge. Samples were collected by connecting the bladder to the extended hose, whereby the hose outlet was kept at the water surface, i.e., moved up the beach with the incoming tide. The measured flow rate is equal to the flow rate measured directly at the seepage meter less a reduction due to flow resistance, i.e., frictional effects in the hose. A laboratory test was carried out to determine the reduction in flow rate due to extended hose length at a head comparable to field conditions. A reduction of $42 \%$ in flow was determined, and corrected for. Both corrected and uncorrected values are reported. The salinity of representative samples during low and high tide 

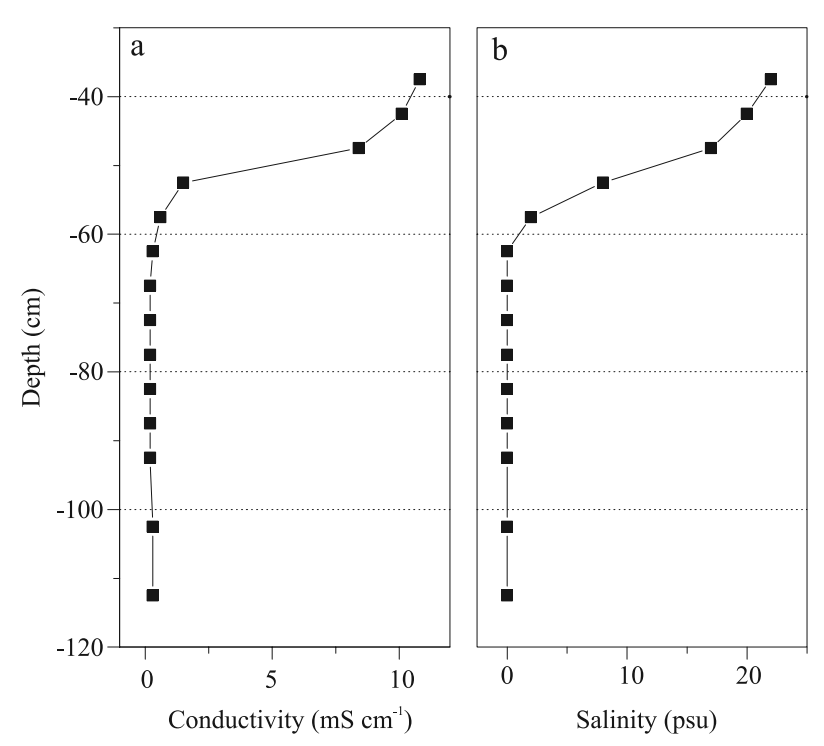

Figure 3. Profiles of (a) bulk ground conductivity and (b) pore water salinity at the same location indicate that low and high bulk electrical conductivity represents pore water of low and high salinity, respectively.

the spring discharge was measured with a Milwaukee MR100ATC handheld refractometer.

\section{Results}

\subsection{Bulk Ground Electrical Conductivity}

[12] The spatial distribution of bulk ground electrical conductivity shows a zone of high conductivity overlying a zone of low conductivity, separated by a well-defined conductivity gradient (Figure 2a). This boundary is irregular in depth but generally dips with increasing distance from shore. Low electrical conductivity extends to a distance of approximately $250 \mathrm{~m}$ seaward in the survey domain. Note that the aquifer may extend further offshore below the survey domain. Low electrical conductivity is found at or close to the sediment surface at the position of spring 081 and discrete locations seaward of spring 081. High and low bulk electrical conductivity is consistent with pore water of marine and terrestrial origin (i.e., seawater and freshwater), respectively, indicating that low bulk electrical conductivity represents pore water of low salinity (Figure 3).

\subsection{Stratigraphy}

[13] Three hand auger and four vibrocores were recovered from representative locations along the transect CS (Figure 2b). Vibrocore compression was 10-15\%. Depths of sedimentary units are reported in reference to the transect datum, whereby core compression was disregarded. Four lithologic units were recovered from the tidal flat, i.e., an upper sand unit above a coral and a clay unit, followed by lower sand unit. The cores extracted from the tidal flat had comparable stratigraphy (Figure 2b), with exception of core EA3 in which two minor clay unit were recovered above and below the coral unit. The origin of the top clay unit is unknown; it is likely reflecting a localized discontinuity. Core EC2 is thus regarded as representative of the principle sedimentary environment on the tidal flat. One additional unit was recovered from the beach face.

\subsection{Grain Size Distribution, Qualitative Mineralogy, and Hydraulic Conductivity}

[14] Grain size distribution analyses revealed that comparable sedimentary units had similar sorting between cores. Thus results for core EC2 only are reported in Table 1. Similarities in mineralogy exist between the lower sand unit (D), core EC2, and sandstone sampled from a weathered dune complex at a site referred to as "Colored Sands", west of Elim Beach (Figure 1). A predominance of quartz is evident for all samples. The sand units $\mathrm{A}$ and $\mathrm{D}$ are of a comparatively high hydraulic conductivity (Table 1 ). The hydraulic conductivity of the coral unit (B) and clay unit (C)

Table 1. Summary of Bulk Mineralogy, Relative Sorting, and Hydraulic Conductivity for the Recovered Stratigraphic Units

\begin{tabular}{|c|c|c|}
\hline Bulk Mineralogy, $>63 \mu \mathrm{m}$ & Sorting & $\mathrm{K}, \mathrm{m} \mathrm{s}^{-1}$ \\
\hline $\begin{array}{l}\text { Unit A }(-22 \mathrm{~cm} \text { to }-72 \mathrm{~cm}) \text { : Medium-bedded sand. Fine to coarse } \\
\text { (predominantly), angular to subrounded quartz grains }(>90 \%) \text {. } \\
\text { Carbonate }(15 \%) \text { and Haematite }(5 \%) \text { distributed irregularly with } \\
\text { minor differences in percentage and distribution evident between } \\
\text { cores. }\end{array}$ & $\begin{array}{l}\text { well sorted } \\
\text { (strongly } \\
\text { unimodal) }\end{array}$ & $1.6 \times 10^{-4}$ \\
\hline $\begin{array}{l}\text { Unit B }(-77 \mathrm{~cm} \text { to }-112 \mathrm{~cm} \text { ): Thick-bedded coral and shell } \\
\text { fragments (approximately } 16-64 \mathrm{~mm}) \text {, occasional fresh but mostly } \\
\text { moderate to highly weathered (appears biologic and chemical } \\
\text { alteration). A. c.f. intermedia and } M \text {. digitata. Matrix of sandy } \\
\text { (medium-coarse quartz) mud and coarse shell grit. }\end{array}$ & $\begin{array}{l}\text { poorly sorted } \\
\text { (polymodal) }\end{array}$ & $5.9 \times 10^{-7}$ \\
\hline $\begin{array}{l}\text { Unit } \mathrm{C}(-112 \mathrm{~cm} \text { to }-125 \mathrm{~cm}) \text { : Thin-bedded sandy clay/silt. Very } \\
\text { fine (predominantly) to coarse, subangular to subrounded quartz } \\
\text { grains }(>95 \% \text { after sieving at } 63 \mu \mathrm{m}) \text {. Grain size distribution } \\
\text { analysis revealed the clay/silt fraction to dominate the unit. }\end{array}$ & $\begin{array}{l}\text { moderately sorted } \\
\text { (bimodal) }\end{array}$ & $1.9 \times 10^{-8}$ \\
\hline $\begin{array}{l}\text { Unit } D(-125 \mathrm{~cm} \text { to }-209 \mathrm{~cm}) \text { : Thick-bedded sand. Very fine to } \\
\text { coarse (predominantly medium), subangular to rounded quartz } \\
(>95 \%) \text {. Complete absence of carbonate. Hematite and reworked } \\
\text { cemented quartz grains, irregularly distributed and variable in } \\
\text { abundance. }\end{array}$ & $\begin{array}{l}\text { well sorted } \\
\text { (unimodal) }\end{array}$ & $2.9 \times 10^{-5}$ \\
\hline $\begin{array}{l}\text { Unit E (cores EA1 and EA2): Thick-bedded peat. Very high } \\
\text { organic content }(>90 \%) \text { with matrix of very fine to medium quartz } \\
\text { grains. Quartz matrix increases down core corresponding with } \\
\text { decrease in organic content. }\end{array}$ & well sorted & $5.5 \times 10^{-6}$ \\
\hline
\end{tabular}



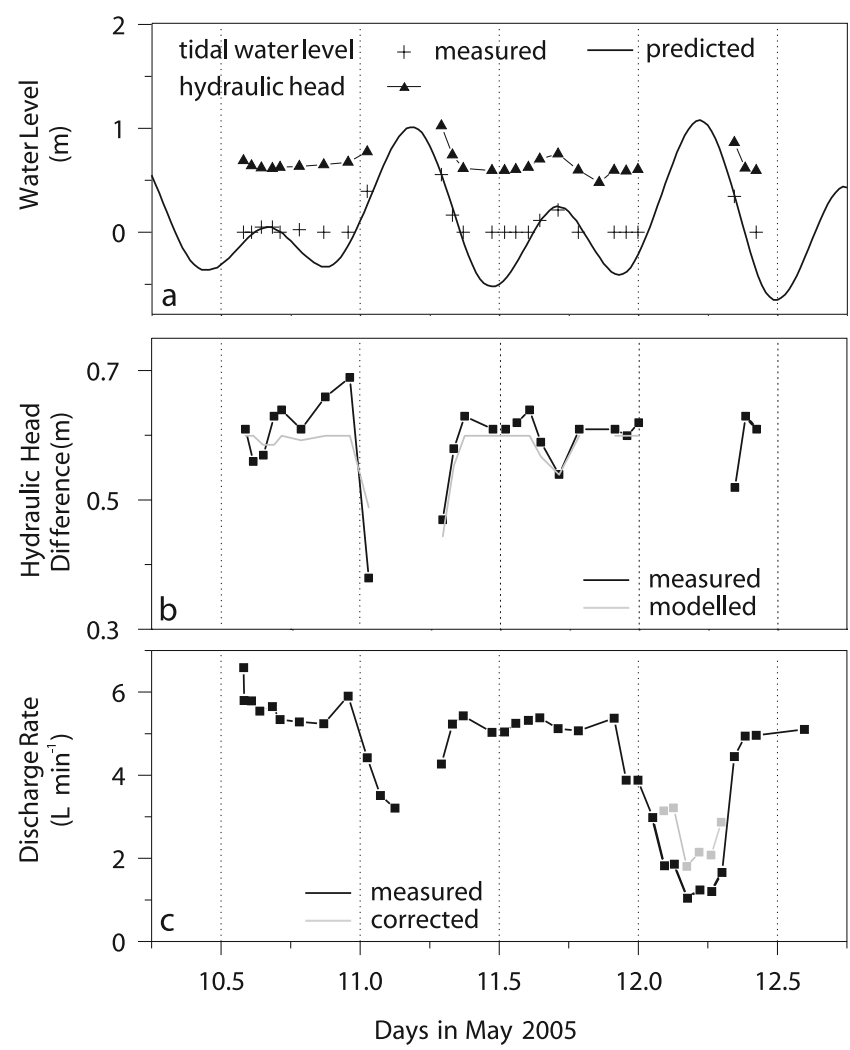

Figure 4. Time series of (a) hydraulic head and tidal water level, (b) hydraulic head difference, and (c) discharge rate, measured at spring 081. In Figure $4 \mathrm{~b}$ the modeled head difference from equation (1) is included; in Figure 4c, measured data are displayed in black, and data corrected for frictional effects due to extended hose length on 12 May are shown in gray. Predicted tide data courtesy of the National Tidal Facility, Australia.

is 2 and 3 orders of magnitude smaller, respectively, than that of the underlying sand unit D.

\subsection{Hydraulic Head and Discharge Rate}

[15] The highest values of hydraulic head difference (water level in standpipe minus tidal water level) at spring 081 over a $36 \mathrm{hr}$ period corresponded to low to midtide with an average maximum value of approximately $62.5 \mathrm{~cm}$ (Figure 4b). A maximum discharge rate from the seepage meter of approximately $5.5 \mathrm{~L} \mathrm{~min}^{-1}$ was recorded (Figure 4c). A reduction in discharge rate occurred in response to increasing tidal water level. The flow rate was not measured at high tide on 11 May, but an expected minimum rate at peak high tide can be calculated to be $2.61 \mathrm{~min}^{-1}$ on the basis of a regression between discharge and tidal water level. The minimum recorded uncorrected flow rate was $1.11 \mathrm{~min}^{-1}$. The uncorrected (underestimated) flow measurements from 12.0 to 12.3 days present a conservative lower limit of the flow rate. Importantly, discharge from the spring did not cease at any time throughout the tidal cycle; that is, no flow reversal as often observed occurred [e.g., Chanton et al., 2003; Sholkovitz et al., 2003]. Correspondingly the hydraulic head difference remained positive, i.e., above tidal water level at all times (Figure 4b). The discharge from the spring had a salinity of zero at all stages of the tide. This is consistent with the observation of continuous discharge, i.e., no flow reversal during high tide. In other words, saline water does not appear to enter the confined aquifer during high tide, and recirculated seawater therefore does not contribute to SGD from the spring.

\section{Discussion}

[16] From the investigated sediment properties, a likely hydrogeological setting of the observed spring discharge can be derived. This includes a palaeodepositional interpretation of the stratigraphic record.

\subsection{Palaeodeposition}

[17] The lower sand units from all cores are interpreted to be dune sands. Both grain shape (subangular to round) and relative sorting are indicative of aeolian deposition. Qualitative mineralogical analyses (not presented here) revealed similarities between unit D and sandstone deposits outcropping approximately $50 \mathrm{~m}$ above sea level at the large sand dune complex "Colored Sands" west of Elim Beach (Figure 1). Pye [1983] suggested that sandstone units are dune deposits of the last interglacial age. Therefore the lower sand unit is most likely late Pleistocene in age owing to the presence of reworked sandstone and cemented quartz grains present throughout the unit in all cores [cf. Pye, 1983]. Extensive dune accumulation probably occurred throughout the Pleistocene low sea level stand and coincided with coastline progradation.

[18] The succession of stratigraphic units corresponds to early to mid-Holocene sea level transgression (10 to approximately $5.5 \mathrm{ka} \mathrm{BP}$ ). The unit of sandy clay may represent a low-energy mangrove environment that migrated landward subsequent to the erosion of the existing Pleistocene dunes by a transgressive shoreline. The presence of clay material indicates a reduction in the depositional energy within the embayment, likely due to tombolo formation. The tombolo joining Cape Bedford to the mainland probably formed subsequent to approximately $6 \mathrm{ka} \mathrm{BP}$ when the sea level was at a position at or above the present-day shoreline [e.g., Larcombe and Carter, 1998]. Subsequent to tombolo formation, the coastal configuration and energy regime for the region was likely similar to that of the present day.

[19] The coral unit may either be a storm deposit or an inshore reef deposit. Coral material may have been pushed onshore in a high-energy storm event. If the unit was deposited before or after the Holocene sea level maximum, there had to have been a temporary rise in sea level, consistent with a storm surge, for coral to be deposited at location EA1 approximately $+0.7 \mathrm{~m}$ above the present-day shoreline (Figure 2). The unit shares similarities with inshore reef deposits found in many fringing reef lagoons in north Queensland. Reef growth within the embayment was most probably at or above the present-day shoreline if the unit was deposited when sea level was at its maximum elevation of $+2-3 \mathrm{~m}$ approximately $6 \mathrm{ka} \mathrm{BP}$ [Larcombe and Carter, 1998]. Given the absence of coral rubble in core EA2 (taken approximately $+1.8 \mathrm{~m}$ above the present-day shoreline), in either scenario it is reasonable to assume that the position of core EA1 marks the approximate maximum landward limit of the coral rubble unit. 
[20] Lowering of sea level between approximately 3.5 to $2.5 \mathrm{ka}$ BP resulted in shoreline progradation and minor dune formation [Larcombe and Carter, 1998]. At Elim Beach, this is evident from the presence of peat in cores EA1 and EA2. The unit of peat is assumed to have originated in a dune wetland since outcrops cooccur with Melaleuca spp. trees at the shoreline. For this to be a freshwater wetland deposit, a fore dune must have stood some distance seaward of this point. On the basis of an approximate accumulation rate of $1.2 \mathrm{~mm} \mathrm{y}^{-1}$ for peat in a humid tropical environment (R. Wust and R. Bustin, unpublished data, 2002), it is estimated that a minimum age of $1.25 \mathrm{ka}$ is required for the accumulation of the $1.5 \mathrm{~m}$ thick peat deposit in core EA2. However, Elim Beach is situated in the dry tropics and is seasonally dry, thus the accumulation of peat would be expected to be slower. A slow rate for peat accumulation of $0.5 \mathrm{~mm} \mathrm{y}^{-1}$ would yield an approximate age of $3 \mathrm{ka}$ (R. Wust and R. Bustin, unpublished data, 2002). In either case, ample time existed throughout the late Holocene regression for such extensive peat accumulation.

\subsection{Hydrogeology of the Aquifer}

[21] Grain size distribution analyses and hydraulic conductivity measurements indicate that both the coral and the clay units (units B and C) have the potential to provide confinement of the Elim Beach aquifer in the intertidal flat. Grain size fractions for both units typically range from very fine silt to coarse sand, and both units are characterized by poor sediment sorting and minimal interstitial spaces, a common characteristic of sediments of low hydraulic conductivity. Both the coral and clay units are significantly less permeable than the sand units (Table 1). However, considering that the spatial extent of the coral unit appears to be limited to the tidal flat only (see above), it is reasonable to assume that the clay unit provides the dominant confinement within, as well as onshore off, the tidal flat. The hydraulic conductivity of the lower sand unit below this confining unit is comparatively high, and the electric conductivity survey indicates the presence of fresh pore water in this unit. Thus this unit is a (confined) aquifer unit.

\subsection{Spatial Distribution of Groundwater in the Intertidal Zone}

[22] The observed distribution of high-conductivity/seawater overlying low-conductivity/fresh groundwater separated by a distinct, sharp interface identifies the location of a shallow confining layer (aquitard). Fresh interstitial water (low electric conductivity) can only extend as far offshore as observed if the aquifer is confined [e.g., Stieglitz, 2005]. The narrow band of low-conductivity freshwater closely above the aquitard is a result of the upward movement of fresh groundwater into the sedimentary layers above the confinement, either by seepage through a semi-impermeable aquitard or through breaches in the aquitard forming springs (Figure 2). Conversely, upward forcing of fresh groundwater by the hydraulic pressure of the confined aquifer, aided by the comparatively lower hydraulic conductivity of the coral and clay units prevents the vertical, downward infiltration of seawater. Typically, below the depth of the aquitard; that is, within the confined aquifer, only low electrical conductivity/freshwater occurs.
[23] High electrical conductivity/seawater penetrates into greater depth with increasing distance seaward, indicating a seaward-sloping aquitard. Between $200 \mathrm{~m}$ and $400 \mathrm{~m}$ along the transect, the interface between low and high electrical conductivity is less well defined, indicating a zone of mixing between low electrical conductivity/freshwater and high electrical conductivity/seawater. This is likely due to a reduced aquifer pressure with distance from shore. Note that the aquifer may continue beyond $300 \mathrm{~m}$ along the transect, but at depths below the survey domain. Low electrical conductivity at the position of spring 081 is uniform with depth and is consistent with the presence of spring discharge of fresh groundwater (Figure 2). The conductivity data indicate preferential forcing of freshwater to the sediment surface at different locations along the transect. Such preferential flow paths can be associated with differences in sediment structure, in particular of the aquitard, occurring at paths of least resistance. At $39 \mathrm{~m}$ and $119 \mathrm{~m}$ along the transect, low electrical conductivity/freshwater occurs close to the sediment surface. No major discharge of freshwater was observed at these positions during the main field investigations; however, 1 week after the main field investigations, a new small spring had appeared at transect position $130 \mathrm{~m}$. At approximately $60 \mathrm{~m}$ along the transect, slightly higher conductivity occurs at depth, most probably resulting from overlying more saline water flowing downward along the conductivity probe at this location.

\subsection{Tidal Forcing of SGD from the Confined Aquifer}

[24] Hydraulic head difference and discharge rate from spring 081 were inversely correlated with tide. With increasing tidal water level, discharge from spring 081 decreased; however, it remained positive throughout the tidal cycle. This implies that the hydraulic head difference must have remained positive throughout the tidal cycle, i.e., above tidal water level. A priori, this is not intuitive: at low tide, the hydraulic head (i.e., the water level in the standpipe) at $62.5 \mathrm{~cm}$ was below the high tide mark of $>100 \mathrm{~cm}$. One would expect the flow from the spring to cease and in fact to reverse when the level of the tide exceeds $62.5 \mathrm{~cm}$. Instead, a rise of the hydraulic head with increasing tidal water level was observed.

[25] Minor fluctuations in water table position and discharge are known to occur in unconfined aquifers caused by tidal pumping [e.g., Turner et al., 1997; Drabsch et al., 1999; Robinson et al., 2006; Taniguchi et al., 2006]. However, the response of the hydraulic head difference in a confined aquifer to tidal forcing is far more significant [Bear, 1979; Townley, 1995; Jiao and Tang, 1999]. Where the hydraulic head at low tide is below the high tide water level, the hydraulic pressure of the confined aquifer must change during the tidal cycle for the hydraulic head difference to remain positive. Because of the presence of an aquitard at Elim Beach, the major influence of tidal forcing must be a differential pressure forcing at its seaward limit, causing temporal variations of the hydraulic pressure of the confined aquifer with tidal water level. In an aquifer system of considerable size, the tidal pressure at the seaward limit of the aquifer is unlikely to result in an elevation of the hydraulic head at its inland boundary. In summary, the continuous elevation of the hydraulic head difference above tidal water level is suggested to be the result of a tide- 

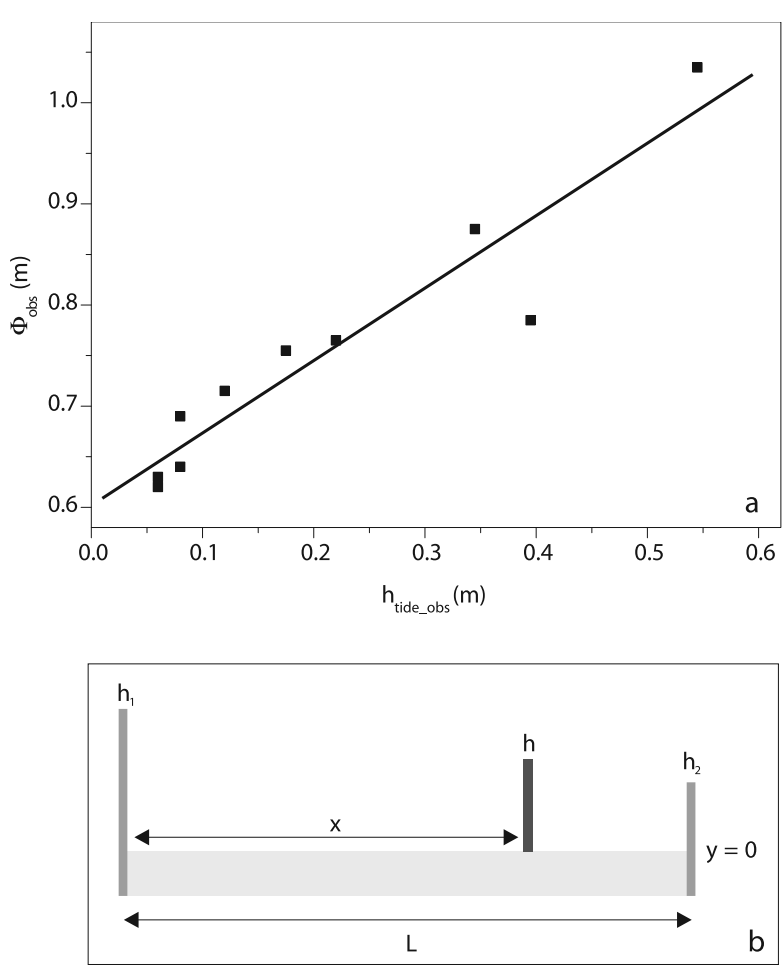

Figure 5. (a) Observed water level $\Phi_{\text {obs }}$ in the standpipe at spring 081 as function of observed tidal water level $h_{2}$ obs above spring 081, together with linear regression function. (b) Schematic confined aquifer; parameters are explained in the text.

induced increase of hydraulic pressure in the confined aquifer at its seaward limit.

[26] The observed water level in the standpipe at spring 081 is linearly related to the tidal water level during tidal inundation (Figure 5a):

$$
\Phi_{o b s}=(0.60 \pm 0.02)+(0.72 \pm 0.09) h_{2 o b s} \text { with } r^{2}=0.89
$$

where $\Phi_{\text {obs }}$ is the observed water level in the standpipe, and $h_{2 o b s}$ is the observed tidal water level at spring 081. This relationship can be examined with a simple hydrological model. Assume a horizontal, confined aquifer (100\% confinement) with length $L$, hydraulic head $h_{1}$ at the landward limit of the aquifer $(x=0)$, and hydraulic head $h_{2}$ on the seaward limit of the aquifer $(x=L)$ as illustrated in Figure 5b, i.e.,

$$
h(x=0)=h_{1} \quad \text { and } \quad h(x=L)=h_{2}
$$

where $h(x)$ is the hydraulic head at distance $x$ (Figure 5b). At the vertical limit of the aquifer the flux will be zero, i.e.,

$$
K \frac{\partial h}{\partial y}=0 \quad \text { at } y=0
$$

Assuming that there is no lag or attenuation of the response of the aquifer to the tidal forcing, the hydraulic head will satisfy Laplace's equation

$$
\nabla^{2} h=0
$$

Assuming no variation in hydraulic head with depth, the exact solution of equation (4) with the boundary conditions in equations (2) and (3) for the water level $\Phi$ at the spring 081 as a function of the tidal water level $h_{2}$ is

$$
\Phi=h_{1}\left(1-\frac{x}{L}\right)+\frac{x}{L} h_{2}
$$

that is, $\Phi$ and $h_{2}$ display a linear relationship. Equation (5) describes a linear increase in hydraulic pressure throughout the confined aquifer caused by the tidal forcing at its seaward limit. In conclusion, a tidal forcing at the seaward limit of the aquifer does explain the water level variations in the standpipe at spring 081 observed during varying tidal stages (Figure 5a). It is useful to establish the validity of the assumption of no attenuation or phase lag of the forcing. Townley [1995] and Jiao and Tang [1999] show that this validity depends on the parameter

$$
\lambda=(\omega S / 2 T)^{0.5}
$$

where $\omega$ is the angular frequency of the periodic (tidal) forcing, and $S$ and $T$ are aquifer storativity and transmissivity, respectively; the attenuation of the signal, phase lag and the combined effects of the attenuation and phase lag are negligible for $\lambda \leq 1$ and small for $\lambda \approx 2$ [Read et al., 2005]. Using the depth of the aquifer $D$, the specific storativity $S_{0}=$ $S / D$ and the hydraulic conductivity $K=T / D$ [Bear, 1979], equation (6a) becomes

$$
\lambda=\left(\omega S_{0} / 2 K\right)^{0.5}
$$

Although no direct estimate of the specific storativity of the Elim Beach aquifer is available, previous research on coastal confined aquifers by Li and Jiao [2001] suggests $S_{0}$ to be of the order of $10^{-6} \mathrm{~m}^{-1}$; with $\omega=4 \pi$ (semidiurnal tides), and $K=2.5 \mathrm{~m} \mathrm{~d}^{-1}$ (Table 1), $\lambda$ is of the order of $10^{-3}$, and thus the assumption of no phase lag and attenuation is valid. Therefore it can be concluded that the approximate model presented here captures the essential hydrological features of the region well.

[27] The limited observational data do not allow for a full examination of the relationship given in equation (5). However, estimates of extent $L$ of the aquifer and the "inland" hydraulic head $h_{1}$ may be made by combining the observed linear relationship of $\Phi\left(h_{2}\right)$ in equation (1) with equation (5). The slope of the function $\Phi\left(h_{2}\right), x L^{-1}$, was determined to be $0.72 \pm 0.09$ at spring 081 ; that is, spring 081 is located at around $72 \%$ of the total length $L$ of the aquifer (Figure 5b). Spring 081 is located at the landward limit of the tidal flat. Assuming that the aquifer extends under the tidal flat for its full length of ca $500 \mathrm{~m}$; that is, $L-x=500 \mathrm{~m}$, then $L$ approximately ranges from $1400 \mathrm{~m}$ to $2600 \mathrm{~m}$. The hydraulic head $h_{1}$ can be estimated similarly from equations (1) and (5), using

$$
h_{1}\left(1-\frac{x}{L}\right)=0.60 \pm 0.02 \text { and } \quad \frac{x}{L}=0.72 \pm 0.09
$$

as ranging between $1.6 \mathrm{~m}$ and $3.3 \mathrm{~m}$. Both estimations of range of aquifer extent and "inland" hydraulic head appear reasonable when considering the local topography. 

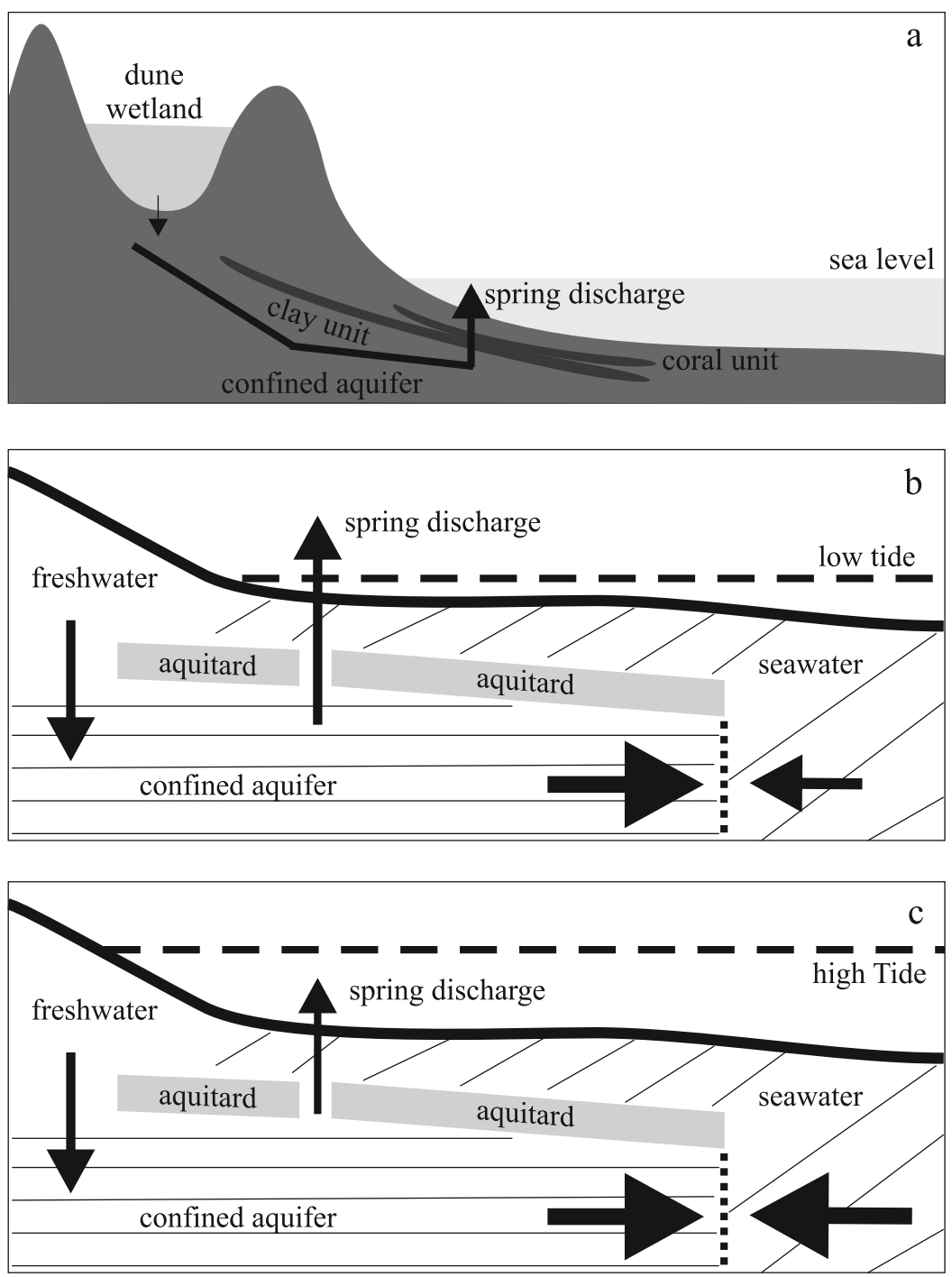

Figure 6. (a) Conceptual hydrogeological model for Elim Beach, north Queensland (modified from Stieglitz [2005]) and hydrological control of discharge at (b) low and (c) high tide. Arrows denote relative hydraulic pressure of the confined aquifer and tidal water pressure. The vertical scale in Figure $6 \mathrm{a}$ is of the order of tens of meters, and in Figures $6 \mathrm{~b}$ and $6 \mathrm{c}$, the vertical scale is of the order of meters.

[28] In addition to these geographic parameters of the aquifer system, it is interesting to obtain an orderof-magnitude estimate of the relative contribution of discharge of groundwater from the springs versus leakage through the confining layer in the intertidal zone. Applying Darcy's Law and assuming an average head difference of $0.5 \mathrm{~m}$ across the confining clay unit (Figure 4), which is of a thickness of the order of $0.1 \mathrm{~m}$ (Figure $2 \mathrm{~b}$ ) and a hydraulic conductivity of $1.9 \times 10^{-8} \mathrm{~m} \mathrm{~s}^{-1}$ (Table 1), the leakage per meter of shoreline of the $500 \mathrm{~m}$ wide intertidal zone is estimated at $2.8 \mathrm{~L} \mathrm{~min}^{-1}$. Thus leakage through the confining layer per $1 \mathrm{~m}$ of shoreline and discharge from breaches in the layer would contribute similar amounts to the total discharge. The total discharge from the approximately $5 \mathrm{~km}$ long shoreline would then be comparable to an annual recharge of $0.5 \mathrm{~m} \mathrm{y}^{-1}$ (50\% of annual rainfall) over an area of $10 \times$ $2 \mathrm{~km}^{2}$, which appears to be reasonable when considering the local geography and rainfall regime.
[29] In summary, an increase in aquifer pressure with rising tide and associated continued flux of groundwater from the confined aquifer when submerged at high tide is due to tidal forcing of the aquifer at its seaward extent.

\subsection{Conceptual Hydrogeological Model}

[30] Combining the discussed observations, a conceptual model of the hydrogeological setting at Elim Beach can be established (Figure 6). The coral and clay units display properties of confining units across the Elim Beach tidal flat. However, for the confined aquifer to be connected to a recharge zone on land, the aquitard must extend inland. Although stratigraphic data are lacking for the inland regions, the derived palaeodepositional history suggests that the clay unit extends onshore of the present-day shoreline, as a result of a low-energy environment migrating landward with the transgressive shoreline during sea level change. In contrast, the coral unit does not extend onshore. It is likely 
that a significant fraction of the local groundwater onshore is confined below the aquitard.

[31] The primary recharge area for the confined aquifer at Elim Beach is the dune system. For discharge to occur perennially from an aquifer that is only recharged seasonally, its storage capacity must exceed the cumulative discharge volume. The local topography suggests lateral aquifer extensions of the order of several kilometers, which is consistent with the simple hydrological model. It is interesting to note that the traditional owners believe that the recharge area extends several kilometers inland from the coast (E. Deemal, personal communication, 2004).

\section{Conclusions}

[32] Discharge of fresh groundwater from discrete springs in the intertidal zone at Elim Beach, north Queensland, was investigated with geological, geophysical and hydrological methods. From geophysical and hydrological investigations and palaeodepositional considerations, it is derived that a clay unit provides confinement of the local aquifer, connecting the aquifer in the tidal flat to an inland recharge zone, with spring discharge occurring where this layer is breached.

[33] Hydraulic head difference and groundwater discharge rate recorded at a representative spring on the intertidal flat were inversely correlated with tidal water level but remained positive throughout the tidal cycle even though the head at low tide was below the high tide mark. A simple analytical model of tidal forcing explains the observed tidal variation of hydraulic head difference and discharge from the confined aquifer. These variations in head difference and discharge in the confined aquifer are a result of tidal forcing at the seaward limit of the aquitard. Such tidal forcing of SGD from a confined aquifer has not been described to date, and is likely to occur in comparable hydrogeological settings elsewhere.

[34] Surface water discharge from rivers or creeks is absent or minimal in the sand dune region. Thus continuous spring discharge of fresh groundwater throughout the tidal cycle, together with the perennial nature as observed by the traditional owners suggests that SGD is a dominant pathway for freshwater entering the ocean in the region.

[35] Acknowledgments. Eddie, Harold, and David Deemal, traditional indigenous owners of Guggu Yimithirr country, are thanked for their permission to work at Elim Beach and for their invaluable help in the field. Severine Thomas and Jeff Cavanagh provided field and technical support, respectively. Comments by Peter Cook, Ling Li, Jordan Clarke, Michael O'Leary, Scott Smithers, and Kevin Parnell are greatly appreciated. This paper has greatly benefited from the thorough review of two anonymous reviewers. This research was funded by an Australian Research Council Discovery grant (ARC DP0209526) and by James Cook University.

\section{References}

Bear, J. (1979), Hydraulics of Groundwater, 569 pp., McGraw-Hill, New York.

Bokuniewicz, H. (1980), Groundwater seepage into Great South Bay, New York, Estuarine Coastal Mar. Sci., 10, 437-444.

Chanton, J. P., W. C. Burnett, H. Dulaiova, D. R. Corbett, and M. Taniguch (2003), Seepage rate variability in Florida Bay driven by Atlantic tidal height, Biogeochemistry, 66, 187-202.

Drabsch, J. M., K. E. Parnell, T. M. Hume, and T. J. Dolphin (1999), The capillary fringe and the watertable in and intertidal estuarine sand flat, Estuarine Coastal Shelf Sci., 48, 215-222.

Jiao, J. J., and Z. Tang (1999), An analytical solution of groundwater response to tidal fluctuation in a leaky confined aquifer, Water Resour Res., 35, 747-751.

Johannes, R. E. (1980), The ecological significance of the submarine discharge of groundwater, Mar. Ecol. Prog. Ser., 3, 365-373.

Larcombe, P., and R. M. Carter (1998), Sequence architecture during the Holocene transgression: An example from the Great Barrier Reef Shelf, Australia, Sediment. Geol., 117, 97-121.

Lee, D. R. (1977), A device for measuring seepage flux in lakes and estuaries, Limnol. Oceanogr., 22, 140-147.

Li, H., and J. J. Jiao (2001), Analytical studies of groundwater-head fluctuation in a coastal confined aquifer overlain by a semi-permeable layer with storage, Adv. Water Resour., 24, 565-573.

Marshall, T. J., J. W. Holmes, and C. W. Rose (1996), Soil Physics, 453 pp., Cambridge Univ. Press, New York.

Pye, K. (1982), Morphological development of coastal dunes in a humid tropical environment, Cape Bedford and Cape Flattery, north Queensland, Geogr. Ann. Ser. A, 64, 213-226.

Pye, K. (1983), The coastal dune formation of northern Cape York Peninsula, Queensland, Proc. R. Soc. Queensland, 94, 33-39.

Read, W. W., T. Stieglitz, and D. Holliday (2005), Modelling submarine groundwater discharge at Elim Beach, paper presented at Pacem in Maribus XXXI Conference, Int. Ocean Inst., Townsville, Queensl., Australia.

Ridd, P. V., and R. Sam (1996), Profiling groundwater salt concentrations in mangrove swamps and tropical saltflats, Estuarine Coastal Shelf Sci., 43, $627-635$.

Robinson, C., B. Gibbes, and L. Li (2006), Driving mechanisms for groundwater flow 1and salt transport in a subterranean estuary, Geophys. Res. Lett., 33, L03402, doi:10.1029/2005GL025247.

Sholkovitz, E., C. Herbold, and M. Charette (2003), An automated dyedilution based seepage meter for the time-series measurement of submarine groundwater discharge, Limnol. Oceanogr. Methods, 1, 16-28.

Stieglitz, T. (2005), Submarine groundwater discharge into the near-shore zone of the Great Barrier Reef, Australia, Mar. Pollut. Bull., 51, 51-59.

Stieglitz, T., P. V. Ridd, and S. Hollins (2000), A small sensor for detecting animal burrows and monitoring water conductivity, Wetlands Ecol. Manage., $8,1-7$.

Taniguchi, M., T. Ishitobi, and J. Shimada (2006), Dynamics of submarine groundwater discharge and freshwater-seawater interface, J. Geophys. Res., 111, C01008, doi:10.1029/2005JC002924.

Timms, B. V. (1986), Reconnaissance limnology of some coastal dune lakes of Cape York Peninsula, Queensland, Aust. J. Mar. Freshwater Res., 37, $167-176$.

Townley, L. R. (1995), The response of aquifers to periodic forcing, $A d v$ Water Resour., 18, 125-146.

Turner, I. L., B. P. Coates, and R. I. Acworth (1997), Tides, waves and the super-elevation of groundwater at the coast, J. Coastal Res., 13, 46-60.

D. Holliday, W. W. Read, P. V. Ridd, and T. C. Stieglitz, Marine Geophysical Laboratory, School of Mathematical and Physical Sciences, James Cook University, Townsville, Queensland 4811, Australia. (thomas. stieglitz@jcu.edu.au) 